\title{
CROSS-BORDER CONSUMPTION AND BRAZILIAN
}

\section{LAW}

Raphael Carvalho de Vasconcelos

Currently Secretary-General of the Court of MERCOSUR. LLM in International Law - Universidade de São Paulo and LLM in International Law - Universidade do Estado do Rio de Janeiro. PhD candidate in International Law - Universidade de São Paulo and $\mathrm{PhD}$ candidate in International Law Universidade do Estado do Rio de Janeiro. Assistent Professor at Universidade Federal Rural do Rio de Janeiro.

Contact: raphaelvasconcelos@panoramaofbrazilianlaw.com

\begin{abstract}
The purchase of a product or service by a consumer directly abroad and the remote consumption of goods are the two main ways in which transnational consumption occurs. This new contractual dynamic - a direct result of the development of transport and communication facilities - has consequences not only for consumer protection but also for trade law. It demands from doctrine, courts and legislators an effort to solve problems arising therefrom. Important lessons can be learned from the application of economic theory to law among the difficulties to fit private international law to constitutional principles. New paradigms proposed by the courts in recent years brought great expectations in the national legal system to the evolution of consumer protection concerning international trade. Theoretical developments are now necessary to elaborate regulatory proposals under trademark and corporate law - with particular attention to financial institutions so as to grant greater protection to the vulnerable consumer assuring security and predictability to the system, which are essential to the correct operation of the market.
\end{abstract}

Keywords: Cross-border consumption - law and economics - private international law - trade law.

\section{INTRODUCTION}

The technological development of communication and transport, the end of trade barriers and the new mechanisms of payment are just some factors involved in the emergence of cross-border consumption. The purchase of a product or service directly abroad by a final purchaser and international trade are the two main forms in which this kind of contract can be identified.

Not all social changes and developments can be predicted by 
legislators at the moment they elaborate the norms, but all those future situations require legal solutions to disputes that may arise. With respect to transnational consumption, the doubts generated by legal gaps result in consequences not only in the context of consumer protection but also in several other fields related to business law. Those consequences demand, first from the courts and then from the legislators, a system of law able to solve disputes and to bring greater certainty and predictability to international trade.

Having the institutional security guaranteed by the stability of legal rules as a parameter, we propose an investigation about the answers given by law to the situations involved with cross-border consumption and a critical and proactive analysis of the preliminary solutions presented by the doctrine and the courts.

The research starts with the approach of law and economics presented in the first part of this work which also brings a brief overview of transnational consumption today.

In the second part, a report of how cross-border consumption is traditionally treated by doctrine and jurisprudence is presented also to demonstrate the difficulties to harmonize private international law with the principles of the Brazilian 1988 Constitution. The same section describes the paradigm proposed by the Recurso Especial no. 63.981/SP and the expectations arising from the evolution of consumer protection in Brazil.

The article's final part analyzes the omissions of the mentioned decision and tries to understand the theoretical developments needed and to elaborate some regulatory proposals under trademark and corporate law, with a special attention to the peculiarities of financial institutions. The present study is an attempt -from the perspective of law and economics- to identify the legal limits for the protection of transnational consumers verifying the current treatment given by the Brazilian legal system to the issue.

\section{CROSS-BORDER CONSUMPTION AND THE COSTS OF LAW}

Consumer law has its origin as specific legal branch -such as the rules governing labor relations- on trade law, this historically autonomous and specialized system of law which regulates the economic activities organized for profit ${ }^{1}$.

1 FORGIONI, Paula A. A evolução do direito comercial brasileiro: da mercancia ao mercado. São Paulo: RT, 2009. pp. 135-136. In the beginning of the XX century labor relations were regulated in Brazil as service by the Civil Code of 1916. Ibid. pp. 151-153.VASCONCELOS, Raphael Cavalho. A liberação do setor de Telecomunicações como opção política de regulação econômica. Ética e Filosofia Politica, v. jur., p. 01-17, 2008. p. 02. Reference to the functional 
The autonomy of consumer law allowed the emergence of specific rules and principles to be applied to relations between suppliers and final purchasers of goods and services. This independent system of law experienced during the twentieth century the direct influence of the recognition of fundamental rights ${ }^{2}$. In fact, trade couldn't remain isolated and was gradually permeated by the so-called human rights, which were celebrated both by jusnaturalistic doctrine as by the positivist protective postwar codes as axioms imposed to law as a whole ${ }^{3}$.

Specifically with respect to Brazilian law, the incorporation of solidarity as a principle in the 1988 constitution had a direct impact on consumer relations, which were suddenly treated as a constitutional matter and inserted among the so-called fundamental rights ${ }^{4}$.

Alongside the new paradigms established by law, new technologies and social behaviors imposed themselves to human relations and demand today solutions to the new problems that have arisen. Technological development has shortened geographical distances and transnational exchange of goods is not anymore exclusively trade between suppliers as long as consumers are also able to easily order products directly abroad.

In this context, most synallagmatic contracts between sellers and consumers present nowadays difficulties of territorial allocation and therefore problems to be bound to a specific national legal system. Consumption, as well as what happened once between traders, turned

concept of firm from Asquini reflected by article 966 of the 2002 Brazilian Civil Code which regulates the subjective concept. BRASIL. Lei n ${ }^{\circ} 10.406$, de 10 de janeiro de 2002. "In verbis": "Art. 966. Considera-se empresário quem exerce profissionalmente atividade econômica organizada para a produção ou a circulação de bens ou de serviços."

2 CANÇADO TRINDADE, Antônio Augusto. A proteção internacional dos direitos humanos e o Brasil. Brasília: UnB, 1998. p. 23. Em DOLINGER, Jacob. Dignidade: o mais antigo valor da humanidade. os mitos em torno da declaração universal dos direitos do homem e da constituição brasileira de 1988. as ilusões do pós-modernismo/pós-positivismo. a visão judaica. Revista do Direito Constitucional e Internacional. Ano 18 - v. 70 - jan.-mar/2010. pp. 24-90. interesting analisis of the human dignity which combines the achievements of the last few centuries with a much greater hictorical concept.

3 FERRAZ JÚNIOR. Tercio Sampaio. Direito constitucional - liberdade de fumar, privacidade, estado, direitos humanos e outros temas. Barueri: Manole, 2007. p. 519. Também em HENKIN, Louis. The age of rights. New York : Columbia University Press, 1990. p. 02.

4 BOBBIO, Norberto. Teoria geral da política - a filosofia e as lições dos clássicos. Trad. Daniela Beccaccia Versiani. Rio de Janeiro: Campus, 2000. p. 481. BRASIL. Constituição, 1988. "In verbis": “Art. 5. (...) XXXII - o Estado promoverá, na forma da lei, a defesa do consumidor. Art. 170. A ordem econômica, fundada na valorização do trabalho humano e na livre iniciativa, tem por fim assegurar a todos existência digna, conforme os ditames da justiça social, observados os seguintes princípios: (...) V - defesa do consumidor.”. Quanto ao termo "positivação", CANOTILHO, J.J. Gomes. Direito constitucional e teoria da constituição. Coimbra: Almedina, 2003. p. 377. 
transnational and involves today commonly several distinct legal orders.

This phenomenon is very clear, for example, on internet purchases with home delivery often performed by official or authorized mail service ${ }^{5}$. Although tax barriers still remain for products imported from sellers established outside the current existing free trade areas and customs unions, few restrictions for products ordered by such means are left except those related to tax obligations of the consumer's domicile ${ }^{6}$.

Besides the online market, buyers can nowadays very easily travel abroad and often include shopping in their touristic plans. The transposition of the physical barriers of the States for business or pleasure is no longer privilege of a select group of the society and the consumption of products directly abroad became more popular.

In trade performed between suppliers, the demand to make international exchange more simple by reducing transport and information costs required a greater legislative effort from States and international organizations. Results of those efforts can be recognized in the rules which promote reduction of uncertainty and contracting risks. These rules represent a considerable part of the current international legal instruments and embody a clear attempt to ensure greater security and predictability to trade with direct impact on transaction costs ${ }^{7}$.

Economic rationality gave strong contributions to simplify international trade and influenced the political decisions taken, for example, at the Uruguay Round negotiations of the GATT. It also played an important role at the design of regional experiences of cooperation and integration such as the European Union, MERCOSUR and NAFTA ${ }^{8}$.

With respect to consumer law, the progress in the transnational legal production was much weaker. The protective shape frequently designed by national legislators in the municipal law for consumer relations places the subject much closer to individual rights then to law and economics.

Despite of the abovementioned difficulties, the possibility of mutual contribution between law and economics to propose solutions to issues of social life is still very important and authors such as Adam Smith and Jeremy Bentham tried to demonstrate already in the

5 Within Brazil regulated by Decreto7962/13.

6 MERCADANTE, Araminta de Azevedo. Os aspectos institucionais da integração latinoamericana. In: Revista de Informação Legislativa Abril-Junho, 1971. p. 74.

7 SZTAJN, Rachel. Os custos provocados pelo direito. Revista do Direito Mercantil, Industrial, Econômico e Financeiro. N ${ }^{\circ} 112$, Ano XXXVI, Outubro-Dezembro/1998. pp. 75-78. p. 76.

8 BACCEGA, Marcus. O comércio, suas funções e sua relevância para o direito internacional público. AMARAL JÚNIOR, Alberto (Coord.). Direito do comércio internacional. São Paulo: Juarez de Oliveira, 2002. p. 29-30. 
eighteenth century the relevance of such an interdisciplinary analysis 9 . This propose of dialogue just became notorious on the second half of the 20th century as Ronald Coase, professor at the University of Chicago, published his "Problem of Social Cost"10.

Traditional doctrine reacts frequently very strongly to the Economic Analysis of Law. The critics point out especially methodological differences between law and economy as a supposedly invincible theoretical factor. It is commonly argued, under this perspective, that while law deals with -ethical and moral- values, economy is founded in results and efficiency ${ }^{11}$.

The adoption of the law and economics approach as prescriptive, if extreme, would easily contradict parameters of substantive law. In Brazil, this perspective would have, as critics very frequently mention, a strong barrier in the fundamental rights established in the Constitution. This concept tends to be, indeed, extremely superficial, since it ignores the possibility of an analytic law and economics approach to law ${ }^{12}$.

Furthermore, it is important to eliminate the mistake of identifying the parameters of the economic approach to law simply with efficiency. On proprety rights, for example, the perspective of transaction costs can be quite useful not only to identify the possibility of promoting general welfare by legislating, but also to avoid undesirable consequences of court decisions.

\section{LAW AND INTERNATIONAL CONSUMER PROTECTION}

Some initiatives to increase consumer protection can be found in international law but consumer law was developed mainly within national legal systems and local codes just rarely rule cross-border trade situations $^{13}$. The Brazilian Consumer Protection Code - in Portuguese, CDC - in force since 1990, has no specific rules to resolve conflicts arising from transnational consumer relations ${ }^{14}$.

It is important to note that the main goal of such protective legislations is to eliminate imbalances that may exist between consumers and suppliers. Several provisions contained in the 1990 Brazilian code are based on the assumption that sellers have an advantage

9 SZTAJN, Rachel. "Law and economics". Revista do Direito Mercantil, Industrial, Econômico e Financeiro. $\mathrm{N}^{\circ} 137$, Ano XVIV, Janeiro-Março/2005. pp. 227-238. p. 227.

10 COASE, Ronald. Harry. The problem of Social Cost. Journal of Law and Economics, vol. 3,1960 .

11 FORGIONI, Paula. Análise econômica do direito: paranóia ou mistificação? Revista do Tribunal Regional Federal $3^{a}$ Região. Número 77 - maio/junho - 2006. pp. 35-61. p. 51.

12 Ibid. p. 54-56.

13 Por exemplo: Organização das Nações Unidas. Resolução no 39/248 - 1985.

14 BRASIL. Lei n ${ }^{\circ} 8.078$, de 11 de setembro de 1990. 
when compared to the final purchaser. This is, in fact, a circumstance present in most contracts of this kind and which without an appropriate legislation would submit the consumer to a position of vulnerability.

Many facts involved with cross-border consumption contribute to imbalance contractual relationship. Diversity of languages, difficulties in obtaining information and complexities concerning international delivery and payment procedures are just a few examples of the asymmetry inherent to international consumption ${ }^{15}$. With respect to information access, it is very difficult to establish long lasting relationships of trust in this sort of contracts in order to reduce transaction costs and promote security and predictability for consumers and decrease their vulnerability ${ }^{16}$.

Neither consumerist legislation nor private international law have specific rules to solve conflicts arising from transnational consumption. General conflict of laws and jurisdiction rules are applied and their structures are frequently not adjusted to the general principles of consumer protection ${ }^{17}$. To this respect, it is possible to conclude that private international law legislations didn't move forward to protect consumers and couldn't follow the axiological changes assimilated by the new constitution.

Even public policy - that private international law principle to protect the local morality able to restrain the application of foreign law and the recognition of foreign decisions - does not fit consumer protection properly because it lacks the power to grant new rights to individuals and can be applied just in a negative sense, i.e. preventing violations of rights ${ }^{18}$.

There are, of course, initiatives such as those in the European Union to create a transnational minimum standard for consumer protection and the Santa Maria Protocol, which bounds jurisdiction to the consumer's domicile within MERCOSUR ${ }^{19}$. Situations not ruled by those regional norms shall end up being solved in Brazil under the traditional private international law system establishing, for example, the applicable law of the domicile of the party that made the offer - the provider - or of the place of the conclusion of the contract - when the

15 MARQUES, Cláudia Lima. A insuficiente proteção do consumidor nas normas de Direito Internacional Privado: da necessidade de uma Convenção Interamericana (CIDIP) sobre a lei aplicável a alguns contratos e relações de consumo. São Paulo: RT, 2002. p. 06. "In verbis": descreve tal assimetria como um "desequilíbrio intrínseco informativo e de especialização entre os parceiros contratuais internacionais face ao status leigo e vulnerável do parceiroconsumidor"

16 FORGIONI, Paula. Teoria geral dos contratos empresariais. São Paulo: RT, 2009. p. 95 ,

17 MARQUES, Cláudia Lima. Op. Cit. p. 22.

18 Ibid. pp. 21-22.

19 Ibid. p 35. 
product was bought abroad.

With respect to the jurisdiction, the provisions available are established in article 12 of the Introduction to the Civil Code of 1942 - known in Portuguese as "LINDB" - and in the articles 88 and 89 of the Brazilian Civil Procedure Code ${ }^{20}$. None of them, in an unsystematic interpretation, presents the possibility to appoint the Brazilian courts as the competent ones to analyze the abovementioned situations related to consumption.

Since CDC entered in force - and its role to promote fundamental constitutional guarantees was recognized - a great part of the scholars understands that the most favorable law shall be applied to protect consumers also in transnational transactions. According to this doctrine, the competent jurisdiction might in all cases be established by the general rule of the consumer's domicile of the $\mathrm{CDC}^{21}$.

There is a strong reaction to the use of Brazilian classical private international law rules to appoint the applicable law and jurisdiction to cross-border consumption controversies because they would tend to benefit providers ${ }^{22}$. The systematic interpretation of the CDC in connection with the constitutional protective axioms is, in fact, much more consumer-friendly than the solution given by the Article 9 of the

20 BRASIL. Decreto-Lei no 4.657, de 04 de setembro de 1942. "In verbis": “Art. 12. É competente a autoridade judiciária brasileira, quando for o réu domiciliado no Brasil ou aqui tiver de ser cumprida a obrigação. $\S 1$ o Só à .autoridade judiciária brasileira compete conhecer das ações, relativas a imóveis situados no Brasil. § 20 A autoridade judiciária brasileira cumprirá, concedido o exequatur e segundo a forma estabelecida pele lei brasileira, as diligências deprecadas por autoridade estrangeira competente, observando a lei desta, quanto ao objeto das diligências." BRASIL. Lei n ${ }^{0} 5.869$, de 11 de janeiro de 1973. "In verbis": "Art. 88. É competente a autoridade judiciária brasileira quando: I - o réu, qualquer que seja a sua nacionalidade, estiver domiciliado no Brasil; II - no Brasil tiver de ser cumprida a obrigação; III - a ação se originar de fato ocorrido ou de ato praticado no Brasil. Parágrafo único. Para o fim do disposto no no I, reputa-se domiciliada no Brasil a pessoa jurídica estrangeira que aqui tiver agência, filial ou sucursal. Art. 89. Compete à autoridade judiciária brasileira, com exclusão de qualquer outra: I - conhecer de ações relativas a imóveis situados no Brasil; II - proceder a inventário e partilha de bens, situados no Brasil, ainda que o autor da herança seja estrangeiro e tenha residido fora do território nacional.“

21 BRASIL. Lei no 8.078, de 11 de setembro de 1990.”In verbis”: “CAPÍTULO III Das Ações de Responsabilidade do Fornecedor de Produtos e Serviços Art. 101. Na ação de responsabilidade civil do fornecedor de produtos e serviços, sem prejuízo do disposto nos Capítulos I e II deste título, serão observadas as seguintes normas: I - a ação pode ser proposta no domicílio do autor; $[\ldots] "$

22 BRASIL. Decreto-Lei no 4.657, de 04 de setembro de 1942. "In verbis": “Art. 9o Para qualificar e reger as obrigações, aplicar-se-á a lei do país em que se constituírem. § 10 Destinando-se a obrigação a ser executada no Brasil e dependendo de forma essencial, será esta observada, admitidas as peculiaridades da lei estrangeira quanto aos requisitos extrínsecos do ato. $\S 20$ A obrigação resultante do contrato reputa-se constituída no lugar em que residir o proponente." 
LINDB which establishes for those cases the jurisdiction and the use of the law of the place where the transaction takes place ${ }^{23}$.

With respect to consumption at distance it is also possible to defend under the traditional choice of law system the unrestricted application of the rule that indicates the law of the party that made the offer - the provider - to the solution of disputes allowing the recognition of choice of forum clauses. At an internet transaction, for example, the provider is the one who makes the offer and his law of residence would govern the dispute, a solution incompatible with the current consumer protection standards ${ }^{24}$.

\section{HUMAN RIGHTS AND CROSS-BORDER CONSUMPTION: NEW PERSPECTIVES}

The lack of specific rules to protect cross-border consumption in the system formed in Brazil by the CDC and all the fundamental principles which recognize the vulnerability of the final consumer, require doctrine and jurisprudence to develop legal mechanisms able to fill in the gaps and to ensure compliance with the constitutional standards.

With respect to the acquisition of products abroad by consumers domiciled in Brazil, a very outstanding judgment that reflects the understanding of Brazilian courts was pronounced ten years ago by the Superior Tribunal de Justiça (not by the Supreme Court - Supremo Tribunal Federal!) - Appeal no. 63.981/SP. The mentioned decision reverted the opinion settled by the first instance which rejected the accountability of Panasonic do Brasil LTDA for defects in products produced by its equivalent corporation in the United States and acquired abroad by a final consumer ${ }^{25}$.

23 Sobre o assunto, CANARIS, Claus-Wilhelm. Pensamento Sistemático e Conceito de Sistema na Ciência do Direito. Introdução e tradução de António Menezes Cordeiro. $3^{\mathrm{a}}$. ed. Lisboa: Fundação Calouste Gulbenkian, 2002.

24 MARQUES, Cláudia Lima. A proteção do consumidor de produtos e serviços estrangeiros no Brasil: primeiras observações sobre os contratos à distância no comércio eletrônico. Revista de Direito do Consumidor, São Paulo: Revista dos Tribunais, Ano 11, nº 41, p. 39-80, jan./mar. 2002, p. 67.

25 SUPERIOR TRIBUNAL DE JUSTIÇA RECURSO ESPECIAL N ${ }^{\circ} 63.981$ SP (1995/0018349 8) - Relator: Min. Aldir Passarinho Júnior. "In verbis": "EMENTA DIREITO DO CONSUMIDOR. FILMADORA ADQUIRIDA NO EXTERIOR. DEFEITO DA MERCADORIA. RESPONSABILIDADE DA EMPRESA NACIONAL DA MESMA MARCA ("PANASONIC"). ECONOMIA GLOBALIZADA. PROPAGANDA. PROTEÇÃO AO CONSUMIDOR. PECULIARIDADES DA ESPÉCIE. SITUAÇÕES A PONDERAR NOS CASOS CONCRETOS. NULIDADE DO ACÓRDÃO ESTADUAL REJEITADA, PORQUE SUFICIENTEMENTE FUNDAMENTADO. RECURSO CONHECIDO E PROVIDO NO MÉRITO, POR MAIORIA." 
The members of the court accepted the arguments of the purchaser referring to several characteristics of international trade nowadays and based their decision on the identity between the corporations and the need to correct the imbalance between consumer and supplier in those international contracts ${ }^{26}$.

The judgment can be, however, strongly criticized for its flimsy analysis of certain key issues directly related to the dispute. The argument of illegitimacy sustained by the Brazilian corporation that the trade relation was established between the consumer and another company was not properly analyzed. The ministers apparently considered that a judge is able to lift the corporate veil to correct consumer vulnerability without checking properly the relation between the national firm and the foreign one ${ }^{27}$.

The decision has also absolutely ignored trademark law and the position of the Brazilian courts on the harmonization of consumer protection and the protection of famous mark remains unclear, for example, with respect to the territorial exhaustion doctrine ${ }^{28}$.

26 SUPERIOR TRIBUNALDE JUSTIÇARECURSO ESPECIALNº63.981 SP(1995/0018349 8) - Relator: Min. Aldir Passarinho Júnior. "In verbis": "I Se a economia globalizada não mais tem fronteiras rígidas e estimula e favorece a livre concorrência, imprescindível que as leis de proteção ao consumidor ganhem maior expressão em sua exegese, na busca do equilíbrio que deve reger as relações jurídicas, dimensionando se, inclusive, o fator risco, inerente à competitividade do comércio e dos negócios mercantis, sobretudo quando em escala internacional, em que presentes empresas poderosas, multinacionais, com filiais em vários países, sem falar nas vendas hoje efetuadas pelo processo tecnológico da informática e no forte mercado consumidor que representa o nosso País.” SUPERIOR TRIBUNAL DE JUSTIÇA RECURSO ESPECIAL No 63.981 SP (1995/0018349 8) - Relator: Min. Aldir Passarinho Júnior. "In verbis": "III Se empresas nacionais se beneficiam de marcas mundialmente conhecidas, incumbe lhes responder também pelas deficiências dos produtos que anunciam e comercializam, não sendo razoável destinar se ao consumidor as conseqüências negativas dos negócios envolvendo objetos defeituosos."

27 SUPERIOR TRIBUNAL DE JUSTIÇA RECURSO ESPECIAL No 63.981 SP (1995/0018349 8) - Relator: Min. Aldir Passarinho Júnior. "In verbis": "Contra razões às fls. 161/171, sustentando, preliminarmente, a falta de prequestionamento. Acrescenta que a ação deveria ter sido promovida perante a Justiça Norte Americana, contra a empresa vendedora, e não contra a ré, que não participou da produção, venda e nem assegurou garantia ao produto. Afirma que apesar de vinculadas à mesma matriz, no Japão, tanto a Panasonic Americana como a Brasileira, ora recorrida, são empresas distintas, que elaboram mercadorias próprias, prestando, cada qual, a sua garantia de forma independente. [...] $]^{\text {“ }}$

28 SUPERIOR TRIBUNALDE JUSTIÇARECURSOESPECIALNº 63.981 SP(1995/0018349 8) - Relator: Min. Aldir Passarinho Júnior. "In verbis": " Por outro lado, o sucesso de suas atividades muito está a dever ao elevado conceito que essa marca mundialmente desfruta, sendo, inquestionavelmente, beneficiada em razão desse conceito e da propaganda mundial que é feita em torno dela. Ora, aproveitando, essa empresa nacional, todas as vantagens que são decorrentes desse conceito mundial, evidentemente que ela tem que oferecer algo em contra partida aos consumidores dessa marca, e o mínimo que disso possa decorrer é o de reparar o 
Despite of those critics, the court has changed the Brazilian paradigms for international consumer protection. On recognizing the passive legitimacy of the Brazilian corporation, the decision pointed a tendency to the expansion of the competence established in article 101, I of CDC granting Brazilian jurisdiction to disputes arising from crossborder consumption when the consumer has his domicile in Brazill ${ }^{29}$.

The recognition of this privilege for consumers is already consolidated in Brazilian doctrine and when definitely incorporated by the courts shall embrace both situations of consumer contracts settle at distance and of consumption abroad ${ }^{30}$.

\section{COSTS AND LIMITS OF TRANSNATIONAL CONSUMER PROTECTION}

As pointed above, consumer contracts were detached from trade law due to its particular characteristics clearly incompatible with equal treatment and absolute submission to the clauses agreed in a contract. Characteristics strongly related to the frequent imbalance between suppliers and final consumers of products and services.

Besides that, a trader - a firm or an individual one - constantly analyzes the risks and therefore the costs of the liabilities assumed or to be assumed. In fact, transaction costs are an intrinsic aspect of trade ${ }^{31}$.

In a context of strictly economic analysis of costs involved, law can play an important role establishing clear legal parameters allowing the parties to foresee consequences and possible liabilities related to commitments to be assumed. The predictability of the enforcement of legal rules is highly desirable to promote efficiency and certainty for trade $^{32}$.

The law and economics approach does not necessarily require rules to prescribe behaviors but the economic rationality can be used as an instrument to promote certainty and predictability to the system. This theory can indeed be used to verify desirable practices - and therefore to be encourage - to achieve collective welfare.

dano sofrido por quem compra mercadoria defeituosa, acreditando no produto."

29 It must be mentioned that the decision didn't analyse the international competence of Brazilian courts and just recognized the passive legitimacy ad causam of the national company. 30 Still controversal in Brazilian doctrine.

31 NORTH, Douglas. Institutions, transaction costs, and the rise of merchant empires. In: TRACY, J.D. (ed). The Political Economy of Merchant Empires - State Power and World Trade, 1350-1750. Cambridge: Cambridge University Press, 1991. p. 22.

32 COASE, Ronald Harry. The nature of the firm. Economica, New Series, Vol. 4, No 16. (Nov. 1937), pp. 386-405. em pp. 390-391 CHEUNG apud FARINA, Elisabeth Maria Mercier Querido. Competitividade: mercado, estado e organizações. São Paulo: Singular, 1997. p. 57. FARINA, ibid, p. 58.,. FORGIONI, Paula. Op. Cit., pp. 75-76. 
With respect to Brazilian law, the constitutional doctrine seems to have great difficulty to embody law and economics principles. Such resistance is mainly due to the apparent incompatibility between economic rationality and the moral prescriptions of the Brazilian 1988 Constitution $^{33}$. When specifically applied to property relations, however, the law and economics approach could be actually very welcome and provide great services to society.

Even if restricted to property issues, there is still a strong prejudice toward the law and economics doctrine - conceived as pragmatic, utilitarian and consequentialist. It is necessary to point out that the establishment of the result as a parameter for analysis does not necessarily opposes the whole theory to the founding principles that guide a legal system. This is not the case to omit constitutional guarantees or to dismiss the application of principles pursuing greater efficiency in legal relations but, instead, to seek in the analytical models of economy the most appropriate balance to law.

The excessive "constitutionalization" of private law proves to be as harmful as the unrestricted application of efficiency to seek individual protection in an unsystematic and unpredictable way disregarding the stability so essentially required by private relations. Harmony between principles and predictability must be, in this context, pursued to maintain the coherence of the legal system and the improvement of its role to regulate social relations.

Security and predictability are so the guidelines of law and economics theory but efficiency alone, however, clearly favors suppliers when used as a parameter to labor and consumer contracts. In this sense, it is to be observed that the warranties established for consumer protection can bring positive consequences to trade and dissipate transaction costs initially found.

A model of such perspective is, for example, the guarantee given to the consumer to recover amounts withdrawn from bank accounts through fraud - very common in Brazil. The financial institution generally assumes the loss immediately and avoids disputes in the courts - which always recognize the liability of the supplier in those cases. They still take, on the other hand, great advantage from the behavior of the clients, whom feel safe and encouraged to continue making use of the same means of payment. The legal security provided by the liability of the financial institutions is reflected in the expansion of transactions and it can easily represent gains able to outweigh the transaction costs assumed ${ }^{34}$.

Economic theory does not oppose itself to the consumer

33 POSNER, Richard A., Economic Analysis of Law. Boston: Little Brown, 1992, pp. 154-158., "The Legal Protection of Children".

34 GRAU, Eros. O estado, a empresa e o contrato. São Paulo: Malheiros, 2005. pp. 15-23. 
protection constitutionally recognized as a fundamental individual right in Brazil. It requires, however, the establishment of clear parameters to legal relationships to enable the appropriate cost analysis. Consumers can and must be protected but the construction of this protection shall take into account all affected individuals and corporations specially with respect to consequences related to other branches of law.

\subsection{Trademarks and Consumer Law}

Intellectual property rights include trademarks, copyright, patents, industrial property and -for some authors- also antitrust law ${ }^{35}$. Although both Industrial property and copyright regulate intangible assets, very relevant differences exist between them mainly with regard to the legal regime applied. While copyright protects the work itself, industrial property protects a technique and its surrounding elements.

The exclusive rights granted by intellectual property law can be very easily connected to protection of knowledge but it is also possible to identify concerns clearly related to antitrust. The balance between traders -according to the security and predictability required by economic theory- is so reached by granting certain rights which constitute in fact limits to trade freedom pursuit over the last centuries ${ }^{36}$.

In this sense, trademark regulation under industrial property rights shows very remarkable concerns related to antitrust. The segregation of the trademark owner -due to the right of exclusive use of the mark in relation to products or services of a specific branch of activity (speciality)- constitutes a clear example of the interface pointed establishing limits to free market, preventing the use of registered distinctive signals by not allowed players.

Misuse characterizes therefore unfair competition but the territorial extent of the protection granted by law and its exhaustion must be established to provide predictability to antitrust law mechanisms. The general rule with this respect prevents the registered owner to block in Brazil the free movement of products placed on the market by itself or by an authorized person.

There is also a peculiar situation involving the recognition of the reputation of a particular mark, which by mitigating the principles of speciality and territoriality shall prevent unjust enrichment related to unauthorized use or unfair competition ${ }^{37}$. By turning the territoriality

35 It is, however, quite hard to include antitrust law in the system of intellectual proprety. The current majoritary theory places antitrust law under public law and industrial proprety under coorporation law.

36 BOBBIO, Norberto. A era dos direitos. Rio de Janeiro: Elsevier, 2004.

37 BARBOSA, Denis Borges. Uma introdução à propriedade intelectual. Rio de Janeiro: Lúmen Júris, 1997. p. 122. 
principle more flexible, fame can hinder the registration of trademarks and their use even in countries where they are not explored. With respect to speciality, a well recognized distinctive element may prevent the registration or even its use also in others branches of products ${ }^{38}$.

The arguments applied to grant protection to famous marks fit very well the aims to protect a consumer who buys abroad or orders on internet a product from a trademark present in the Brazilian market. If the industrial property rights system recognizes an advantage to the owner as a result of its fame, liabilities arising out of this global recognition may also be recognized to protect consumers.

In this context, it must be pointed that the famous mark protection theory reflects interests of owners absent of a particular market and that in the leading case here analyzed and among the aforementioned hypothetic situations, the use of the trademark in Brazil would motivate cross-border consumption. If trademark law promotes greater security to the owners and reduces their costs granting protection worldwide, they should also be in charge of any liabilities arising from its products worldwide.

Another important situation to be noted is the possibility -suggested by the doctrine and recognized in the Brazilian Intellectual Property Code- for owners to hinder the commercialization of products -even legally imported- without their consent ${ }^{39}$. This reflects the understanding that a trademark can be used in a given territory -usually corresponding to a specific legal order- and especially that Brazilian law adopts the doctrine of internal exhaustion, ie, the recognition of the right of the owner to fight against any violations so far he, or someone with his consent, introduces the product that uses his trademark in the domestic market.

Unlike the conclusions drawn from the famous mark protection, the internal exhaustion may serve as a counterargument to the protection of the consumer who buys the product directly overseas, for example during a trip. This second argument can so be used against consumers as a parameter for the liability of trademark owners and is founded in the lack of consent for the introduction of the product in the domestic market. This construction does not exclude, however, the famous mark protection arguments which, without much difficulty, could still thrive.

With respect to consumption at distance, the internal exhaustion would not prosper. Sending the product to the consumer implies consent to the introduction of it in the market. Finally, if there is no identity between supplier and the famous mark owner, arguments related to internal exhaustion can, in fact, be used but not against the consumer,

38 Ibid. p. 256.

39 BRASIL. Lei no 9.279, de 14 de maio de 1996. ADIERS, Cláudia Martins. Aspectos polêmicos da propriedade intelectual. Rio de janeiro: Lúmen Júris, 2004. p. 35. 
instead between suppliers and producers.

\subsection{Consumer Law and Corporations}

Structured between consumer law and trademark protection, the arguments that extend to global market the accountability for the product based on reputation usually don't consider, however, the frequent lack of identity between the national corporations that use global advertisement and the foreign business associations which are somehow engaged in transnational commerce.

The confusion between the corporation and its shareholders arises very frequently in jurisprudence, doctrine and even in the choices of the national legislator. The historical preference given to controllers in the legal discipline of companies leads, for example, to confusion and grants to minority shareholders often the selling of shares as the only alternative to disagreements related to decisions taken by the majority shareholders ${ }^{40}$.

Even not being possible to bind the aforementioned preference for the controlling partners to economic theory, one can realize at the importance given to the hierarchical element on the concept of firm an identity with the effective exercise of power within a society ${ }^{41}$. The role of relations of power in the contracts within the company - ie "the firm" - is strongly criticized by the ones that point the necessity to extend this concept to include, for example, contractual relations established between the company and its consumers and suppliers ${ }^{42}$.

Consistent arguments can be extracted from such doctrinal overview to recognize the accountability of national corporations that explore the famous mark in the domestic market for consumer contracts established abroad between an individual and a different - even when apparently similar - company. This can be considered as such by the inclusion of the final purchaser in the concept of firm, as sustained by the critics of the theories of Coase, or - specifically with respect to the defendant controlled by the foreign holder of the famous mark - by overvaluing the hierarchical factor.

The extension of liability becomes an increase of risks for market players and tends to be taken into account by investors at the moment they decide -or not- to join a corporation ${ }^{43}$. Recognizing the importance

40 BULGARELLI, Waldirio. Regime jurídico da proteção às minorias nas S/A. Rio de Janeiro: Renovar, 1998.

41 COASE, Op. Cit. p. 395. Também em SZTAJN, Rachel. Teoria jurídica da empresa. São Paulo: Atlas, 2004. p. 71.

42 Critics to this theory points the inclusion in the concept of firm of contracts that are not part of it.

43 SZTAJN, Rachel. Op. Cit.. p. 75. 
of individuals as human beings, legal rules shall protect vulnerabilities and economic analysis does not oppose itself to it and merely requires from law the establishment of clear rules able to bring greater certainty and predictability and to reduce, consequently, transaction costs. The certainty in the enforcement of rules in case of noncompliance allows contractors to adapt themselves to it and this predictability tends to neutralize effects previously considered harmful.

To reduce transaction costs does not mean thereby to eliminate them. The permanent improvement of exchange of scarce resources requires the existence of transaction costs, which - once removed - would lead to random exchanges with consequent loss of allocative efficiency ${ }^{44}$. Assuming that some risks can not be completely eliminated or even reduced, economic theory points the necessity of legal intervention to correct certain market failures ${ }^{45}$.

In the context here analyzed, the domestic recognition of full accountability of a corporation controlled by a foreign famous mark owner tends to ignore, for example, the position of minority shareholders. Once settled transnational protection in those terms, domestic investors - which are not part of the group of controllers - would be liable for risks assumed by controllers in another jurisdiction.

Minority shareholders shall be properly informed about the worldwide use of the trademarks associated to the company and periodically communicated about the liability supported by other corporations for product failures or defects related to the use of those famous mark abroad. The reduction of information asymmetry could prevent the attraction of speculative investors to the minority block of shareholders. In fact, the relationship between controllers and minority shareholders create a natural gap in the information access but situations of strong power concentration and of appropriation of corporate institutions by a specific group can intensify this imbalance and generate an adverse selection that could keep non mere speculative investors away ${ }^{46}$.

The international accountability of a transnational corporation that has among its partners - controllers or not - the owner of a foreign famous mark must be carefully regulated to allow investors to measure the transaction costs - risks - involved in the acquisition of shares. An alternative would be to establish compensation mechanisms able to transfer exclusively to the owner of the famous mark the responsibility

44 Ibid. p. 76.

45 FORGIONI, Paula. Op. Cit. descreve em pp. 42-43 as falhas de marcado, a saber: assimetria de informações, existência de poder econômico, externalidades e os bens públicos.

46 Estudo detalhado dos efeitos da seleção adversa em AKERLOF, George. The market for lemons: qualitative uncertainty and the market mechanism. Quarterly Journal of Economics. 84 (1970): 488-500 
for product defect related to foreign markets. An example would be the compensation of the liabilities incurred by the company with the dividends to be received by the partner that holds the famous mark privileges. Legislative efforts are in both cases needed to accommodate consumer protection and corporate law.

It is also important to consider a judiciary approach to liability to include the responsibility of licensees of a famous mark for questions arisen from consumption relations performed abroad. Even been this approach compatible with the theory of the firm from Coase, this confusion would exceed all logical interpretations of personal rights and conform an unjustifiable excess in consumer protection.

Prescribing risks without establishing an appropriate regulation can draw in great damage to the market and consequently to the society. The increase in the costs of the global firm by forcing it to assume liability for worldwide transnational consumer contracts may affect, for example, the cost for capital expansion ${ }^{47}$. In the case of licenses, the extension of liabilities for those contracts to mere licensees could even impair the operation of famous marks in Brazil.

\subsection{Objective Limits: Transnational Consumption and Banking Services}

The expansion of the liability of global corporations for worldwide consumption has, however, some objective limits related to peculiarities of specific fields of activity.

Financial institutions, for example, even if legally recognized as trade companies regulated by the Article 966 of the Brazilian Civil Code - and also by consumer law statutes - have certain characteristics that would prevent any transnational liability ${ }^{48}$.

The main barrier for the aforementioned liability has to do with the activity of those corporations: money. The main point is that currency, at least in Brazil, is not legally recognized as a good. The special treatment given to financial activity is due to the public interest related to the control that each state may have over its currency as an instrument to regulate the economy.

The liability of a national corporation for transactions of other companies abroad could reduce the regulatory control exercised by the state on this specific sector and allow, for example, the import of foreign systemic crises. Such peculiarities must be therefore considered by the national judiciary in the evolution of consumer protection.

47 COASE, Op. Cit.

48 Superior Tribunal de Justiça - SUMULA 297: “O Código de Defesa do Consumidor é aplicável às instituições financeiras". 


\section{CONCLUSION}

Transnational consumption - the acquisition of goods by consumers directly abroad or at a distance - is today an irreversible social phenomenon. The complexity of those new legal relations frequently represents, however, a challenge to law. Doctrine and jurisprudence are currently faced with some difficulty to harmonize the protection of vulnerable consumers with the discipline of corporation law which regulates most of cross-boarder relations.

In fact, the development of international trade law seems not to be appropriate to solve problems presented by those new contractual sinalagmas. International consumer contracts - at least in theory - lay under the system of private international law, which in Brazil did not fitted itself satisfactorily to the constitutional command of consumer protection. The courts try, for example at the Recurso Especial no. 63981, to make the protection of vulnerable consumer effective, but, in doing so, they are currently failing to present consistent answers to questions that involve trademark and corporate rights.

The use of the law and economics perspective, as here proposed, may bring positive contributions to give consistency between vulnerable protection and market interests establishing as a parameter the search for greater security and predictability to international trade.

Specifically with regard to the protection of so-called famous marks, the rights granted by industrial property law may fit the arguments for expanding the liability of transnational traders. The benefits conceded regarding the famous mark submit the owner to the liabilities derived by the universalization of his market. Trademark law can so work as a strong ally of international consumer protection.

From the perspective of corporate law, however, the solutions lately presented by the courts often represent a threat. The domestic company that uses the foreign famous mark should not be randomly confused with its foreign partner. The elimination of this confusion is important to avoid an unnecessary increase of risks by circumstances absolutely strange from the shareholders of the local company which are exclusive in the domestic market partners of the foreign corporation that holds the mark worldwide. Such an extended theoretical construction, if irresponsibly applied, could even allow the absurd expansion of the liability of mere licensees, completely strange to the original legal relationship.

The consumer protection can -and should- legitimately generate transaction costs and require the internalization of obligations by suppliers of products. Clear rules and even the possibility of compensation for third parties are, however, extremely necessary to grant certainty and predictability to trade relations. Certain sectors of 
the economy, as for example banking services, require closer attention and specific regulation due to the public interest involved in the activity.

The consumer must be protected by law and this is so also when the law and economics perspective is applied. In this context, the role of the legislators becomes extremely important and urgent to fit, for example, the current private international law and corporate law rules to the constitutional provisions reflected in the Brazilian Consumer Protection Code. While such adjustments are still not available, courts must carefully solve the disputes related to this matter avoiding threats to the market and to third parties which were not involved in the original legal relationship.

\section{REFERENCES}

AKERLOF, George. The market for lemons: qualitative uncertainty and the market mechanism. Quarterly Journal of Economics. 84 (1970): 488-500

ADIERS, Cláudia Martins. Aspectos polêmicos da propriedade intelectual. Rio de janeiro: Lúmen Júris, 2004.

BACCEGA, Marcus. O comércio, suas funções e sua relevância para o direito internacional público. AMARAL JÚNIOR, Alberto (Coord.). Direito do comércio internacional. São Paulo: Juarez de Oliveira, 2002. BARBOSA, Denis Borges. Uma introdução à propriedade intelectual. Rio de Janeiro: Lúmen Júris, 1997.

BOBBIO, Norberto. Teoria geral da política - a filosofia e as lições dos clássicos. Trad. Daniela Beccaccia Versiani. Rio de Janeiro: Campus, 2000.

. A era dos direitos. Rio de Janeiro: Elsevier, 2004

BULGARELLI, Waldirio. Regime jurídico da proteção às minorias nas $S / A$. Rio de Janeiro: Renovar, 1998.

CANARIS, Claus-Wilhelm. Pensamento Sistemático e Conceito de Sistema na Ciência do Direito. Introdução e tradução de António Menezes Cordeiro. 3 . ed. Lisboa: Fundação Calouste Gulbenkian, 2002.

CANÇADO TRINDADE, Antônio Augusto. A proteção internacional dos direitos humanos e o Brasil. Brasília: UnB, 1998.

CANOTILHO, J.J. Gomes. Direito constitucional e teoria da constituição. Coimbra: Almedina, 2003.

COASE, Ronald Harry. The nature of the firm. Economica, New Series, Vol. 4, Nº 16. (Nov. 1937), pp. 386-405.

$\overline{3,1960}$.

. The problem of Social Cost. Journal of Law and Economics, vol.

COMUNIDADES EUROPÉIAS. Diretiva 93/13/CEE. 1993.

DOLINGER, Jacob. Dignidade: o mais antigo valor da humanidade. 
os mitos em torno da declaração universal dos direitos do homem e da constituição brasileira de 1988. as ilusões do pós-modernismo/ pós-positivismo. a visão judaica. Revista do Direito Constitucional e Internacional. Ano 18 - v. 70 - jan.-mar/2010. pp. 24-90

FARINA, Elisabeth Maria Mercier Querido. Competitividade: mercado, estado e organizações. São Paulo: Singular, 1997.

FERRAZ JUNIOR. Tercio Sampaio. Direito constitucional - liberdade de fumar, privacidade, estado, direitos humanos e outros temas. Barueri: Manole, 2007.

FORGIONI, Paula. Análise econômica do direito: paranóia ou mistificação? Revista do Tribunal Regional Federal $3^{a}$ Região. Número 77 - maio/junho - 2006. pp. 35-61

. A evolução do direito comercial brasileiro: da mercancia ao mercado. São Paulo: RT, 2009.

. Teoria geral dos contratos empresariais. São Paulo: RT, 2009.

GRAU, Eros. O estado, a empresa e o contrato. São Paulo: Malheiros, 2005.

HENKIN, Louis. The age of rights. New York : Columbia University Press, 1990.

MARQUES, Cláudia Lima. A proteção do consumidor de produtos e serviços estrangeiros no Brasil: primeiras observações sobre os contratos à distância no comércio eletrônico. Revista de Direito do Consumidor, São Paulo: Revista dos Tribunais, Ano 11, nº 41, p. 39-80, jan./mar. 2002.

- A insuficiente proteção do consumidor nas normas de Direito Internacional Privado: da necessidade de uma Convenção Interamericana (CIDIP) sobre a lei aplicável a alguns contratos e relações de consumo. São Paulo: RT, 2002.

MERCADANTE, Araminta de Azevedo. Os aspectos institucionais da integração latino-americana. In: Revista de Informação Legislativa Abril-Junho, 1971.

NORTH, Douglas. Institutions, transaction costs, and the rise of merchant empires. In: TRACY, J.D. (ed). The Political Economy of Merchant Empires - State Power and World Trade, 1350-1750. Cambridge : Cambridge University Press, 1991.

ORGANIZAÇÃO DAS NAÇÕES UNIDAS. Resolução nº 39/248 1985.

POSNER, Richard A. Economic Analysis of Law. Boston: Little Brown, 1992

SUPERIOR TRIBUNAL DE JUSTIÇA. RECURSO ESPECIAL N ${ }^{\circ}$ 63.981 SP (1995/0018349 8) - Relator: Min. Aldir Passarinho Júnior. SZTAJN, Rachel. Os custos provocados pelo direito. Revista do Direito Mercantil, Industrial, Econômico e Financeiro. N No112, Ano XXXVI, Outubro-Dezembro/1998. pp. 75-78. 
. Teoria jurídica da empresa. São Paulo: Atlas, 2004.

. "Law and economics". Revista do Direito Mercantil, Industrial,

Econômico e Financeiro. N ${ }^{\circ} 137$, Ano XVIV, Janeiro-Março/2005. pp. 227-238.

VASCONCELOS, Raphael Cavalho. A liberação do setor de Telecomunicações como opção política de regulação econômica. Ética e Filosofia Política, v. jur., p. 01-17, 2008. 